\title{
(20)
}

\section{FOOD AND AGRICULTURE ORGANIZATION OF THE UNITED NATIONS}

THE FAO PROGRAMME IN AFGHANISTAN

1988-1997

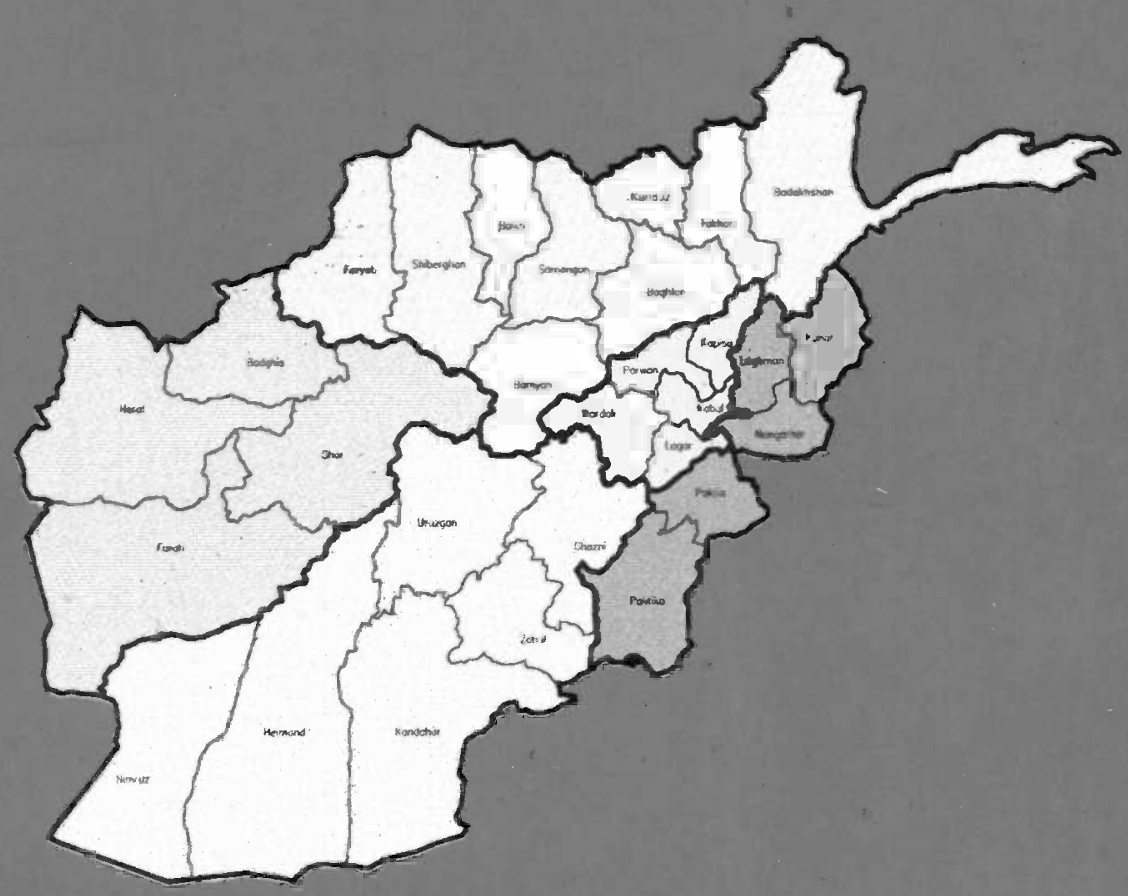

OFFICE OF FAO AFGHANISTAN

NOVEMBER 1995 


\section{FOOD FOR ALL}

World Food Day Theme 1995

"Approaching the third millennium, the world still faces a crucial challenge to the most basic human right: freedom from hunger"

Dr Jacques Diouf

Director General FAO 

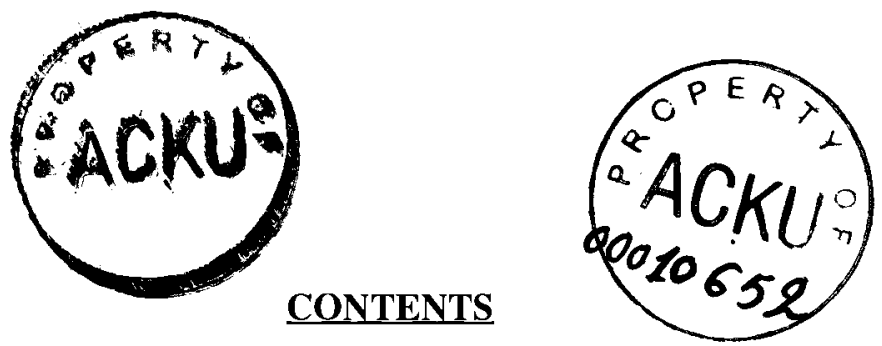

FOREWORD

1. OBJECTIVE 3

2. INTRODUCTION. 3

3. IMPLEMENTATION STRATEGIES 5

4. FAO'S PROGRAMME .......................................................... 8

4.1 IRRIGATION REHABILITATION .................................... 9

4.2 SEED SUPPLY AND PRODUCTION WITH MATCHING FERTILIZER

I) WINTER CROPS ......................................................... 12

II) SUMMER CROPS ....................................................... 20

III) HORTICULTURE ................................................... 21

4.3 LIVESTOCK HEALTH AND PRODUCTION …….............. 23

I) HEALTH ........................................................................... 23

II) POULTRY PRODUCTION ......................................... 26

5. PROMOTING PEACE ........................................................... 27

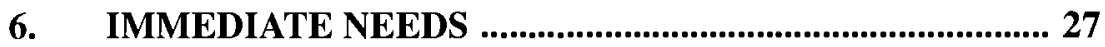

COST-SHARING PRIORITIES ............................................ 28

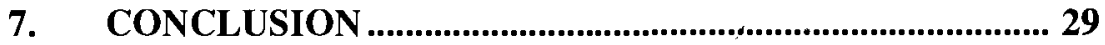




\section{FOREWORD}

This brochure has been prepared as a follow-up both to World Food Day 1995 and the UN Consolidated Inter-Agency Appeal for Emergency Humanitarian and Rehabilitation Assistance for 1995 to 1996.

World Food Day 1995, which also commemorated the 50th Anniversary of the founding of FAO, focussed on perhaps the most base human right of all; freedom from hunger. Whilst exceptional results in food production have been achieved in the face of unprecedented population growth - average cereal yields have been lifted from 1.4 to 2.7 tonnes/hectare; per capita availability of food from 2,300 calories/day to 2,700 - more than 800 million people are still chronically undernourished. 200 million of them are children. Much remains to be done.

Afghanistan mirrors the world in this respect. By 1995 over half the farmers of Afghanistan use improved seed, which has raised yields for them from one to approximately 2.5 tonnes/ hectare. The horticulture sub-sector has been re-established. Animal health services are being delivered in 236 of the 332 districts of the country. Yet, as a legacy of 14 years of war, there remains a food deficit which, according to our guesstimate, is around 700,000$800,000 \mathrm{MT}$, horticultural production is not meeting subsistence demands, livestock health services do not cover the whole country, livestock productivity is low and the forestry sector, to say the least, is neglected. Much remains to be done. 
This brochure briefly describes what is being done and what needs to be done to assist Afghan rural communities in emergency agricultural rehabilitation. Most of the material was prepared for a briefing of donors by the United Nations and NGOs in Stockholm from 1-2 June 1995, and has been updated and expanded to more accurately reflect FAO's present activities. In describing FAO's programme in Afghanistan from 1988 - 1997 it seeks to demonstrate a capacity, together with its Implementing Partners, to deliver substantial support to farming communities in their efforts to rehabilitate their agricultural system. It makes the point that the vast majority of rural communities in Afghanistan are at peace and that the programme is providing substantive support to continuance of the peace process.

The last section provides one-line statements of the cost sharing assistance that is needed to maintain, at a minimum level, the present emergency programme through to 1997. It is important to note that these projects will be operated under the umbrella of FAO's core programme in the crops and livestock sub-sectors of agriculture. This strategy maximizes the integration of projects into the whole programme and minimizes overhead costs.

We hope that you find the brochure informative and that it stimulates additional support to Afghanistan's agricultural rehabilitation programme.

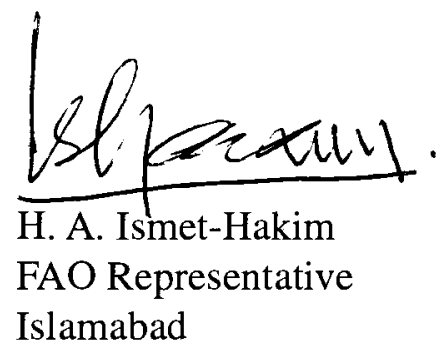

November 1995 


\section{THE FAO PROGRAMME IN AFGHANISTAN}

$\underline{1988-1997}$

\section{Objective}

The fundamental aim of the programme being executed by FAO is to develop a diversified agricultural production system in all accessible areas of Afghanistan which will, simultaneously, ensure a secure supply of food and increasing levels of family and national income, produced in such a way that the quality of the environment is preserved for future generations.

\section{Introduction}

Figure one shows the population distribution in 1987. High population densities are in the east, medium levels in the north and low population densities in most of the western region of Afghanistan.

Approximately $75 \%$ of the population is rural and almost all rural families own livestock. The crucial agricultural products for subsistence needs are wheat, rice, maize, sheep meat, milk and skins.

And the food production base is heavily dependent on irrigation. Prior to the war, irrigated land produced $85 \%$ of all food and agriculture crops, including $77 \%$ of the nation's wheat harvest. 


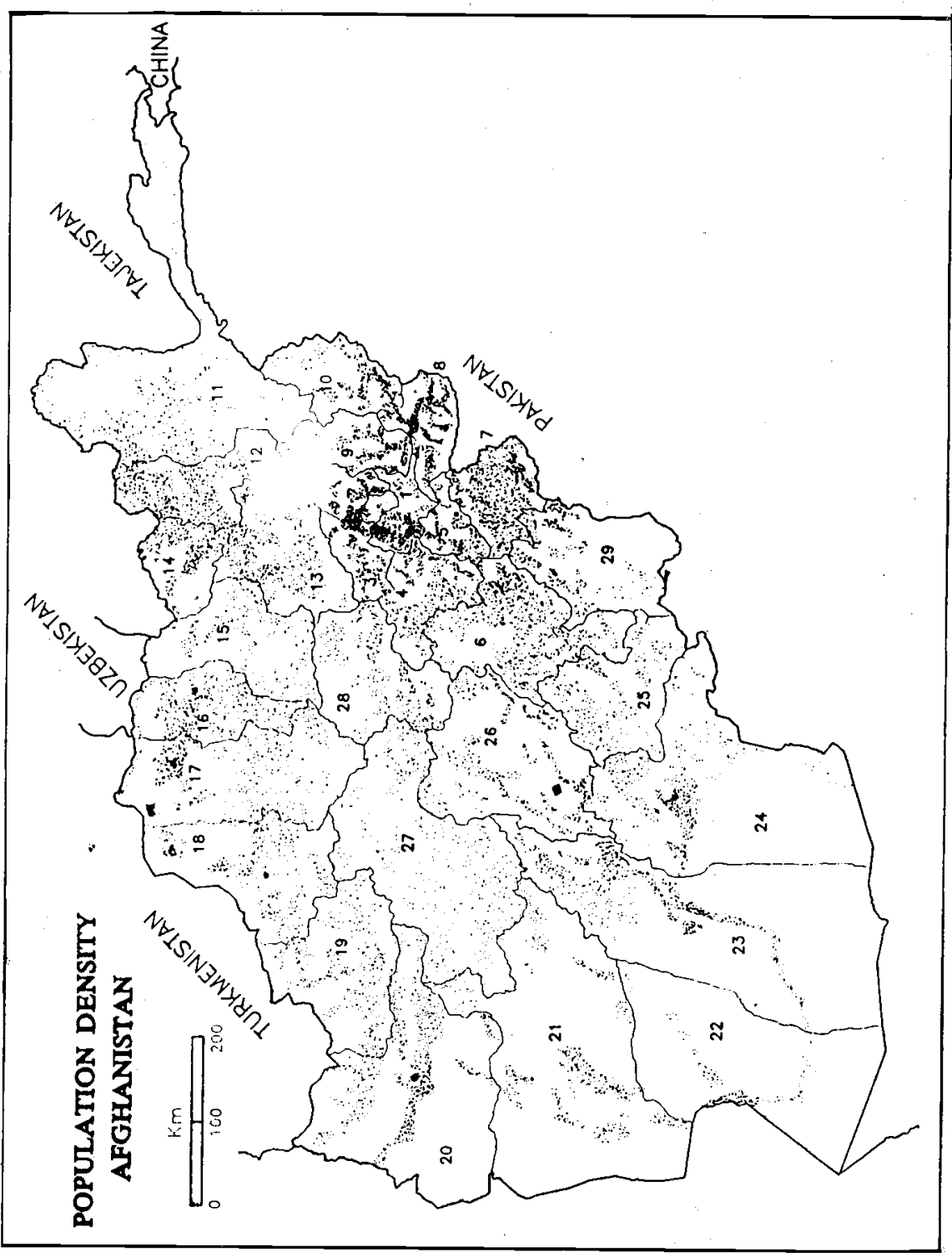




\section{Implementation Strategies}

\section{A phased approach}

The first phase of the programme is to restore the core components of the food base by repairing traditional irrigation systems, by replacing old, disease-susceptible varieties of the staple crops with high quality, high yielding, disease resistant planting material and by establishing a financially and technically sustainable animal health delivery system to village level. The second phase, without neglecting the maintenance of the first, is to diversify into crops of higher value than the staples, adding livestock production elements to animal health and incorporating environmental rehabilitation aspects (such as forestry and the control of soil salinity) into the programme. A third phase can be envisaged which, without neglecting the spread (geographically and within sub-sectors) and maintenance of phases one and two, would focus on the management of natural renewable resources, and secondary processing to increase rural incomes and levels of employment.

\section{Strategies}

Strategies in the initial stages are decided by the availability of delivery mechanisms as determined by historical circumstances, and the immediate reality of the situation. FAO's programme in Afghanistan had continued throughout the war years and in view of this situation its implementation was decentralized through developing separate projects for the east, south and the north of the country.

FAO's initial efforts in Afghanistan were to provide agricultural inputs to returning refugees in time for the planting season. 22,000 tonnes of seed, planting materials, farm tools, and fertilizer were shipped "cross border" by UN agencies. FAO carried out the programme by working with those in control of the areas in question. FAO ensured that Afghan farmers had access to high yield wheat seed and, in order to avoid creating dependency on im- 
ported seed, its experts focused on local production of seed that draws on an international gene pool but is adapted to Afghanistan's conditions.

In the south and east, where government institutions were severely affected by the war, the focus of rehabilitation is on the delivery of small quantities of high quality planting material (the staple crops, orchards crops and trees) with matching fertilizer in widely dispersed locations. With irrigation, the entire irrigation system of the valley is surveyed before work priorities are set. This includes the naming and mapping of all canals, identifying the sites for, and types of repair needed and linking each site to the population and command area affected. Work priorities are then set according to access (with respect to mines), population, size of the command area and approximate cost. To assist in carrying out the tasks, NGOs became one of the types of organizations accepted as Implementing Partners. It has been a very successful partnership: planting material has been delivered to districts which, otherwise, would have been inaccessible and Afghan professionals, who will be the agricultural technocracy in the private and public sectors of a future Afghanistan, have been kept close to Afghanistar working in face-to-face contact with their rural communities. The system is now expanding by contracting NGOs to develop mobile, districtlevel seed production units utilizing contract seed growers. The units are expected to be self supporting in a period of about three years. The strong backstopping and monitoring component of FAO's strategy (through, for example photographs of stages completed in the construction of irrigation structures, and frequent visits of national professional staff to project sites) has been a crucial element in ensuring effective delivery.

In contrast with the micro-projects of the southwest, FAO officers in the north had begun working through the governmentowned seed production corporation based in Kabul, and later, due to fierce fighting, had moved to sites near Mazar-I-Sharif and Herat. As a result, over 14,500 tonnes of seed were produced and 
experienced Afghan staff were retrained in their own country. To the surprise and delight of FAO experts, Afghan farmers attached such value to the locally-produced seed that they were willing to pay higher than market prices for it.

Today similar strategies guide FAO's work with rice, maize, vegetables, sugar, fodder crops and fruits.

In crop protection (confined mainly to Sunnpest and Locust control) communities were asked to identify one of their literate farmers to be trained on the control of Sunnpest and Locust. They would then train farmers, and those who passed would receive authorization to purchase chemicals and to use sprayers. The Crop Extensionists (as they were called) were paid an allowance for conducting the training sessions and for follow-up with farmers. A recent OXFAM study of the system in Faryab province indicated a very high level of success in terms of the area controlled, crop loss avoided and the positive attitude and sense of ownership of the system by rural communities. Whilst the impact was high, its spread in terms of communities covered and pest/disease problems controlled needs to be substantially increased.

With respect to veterinary services, the strategy is to pursue a privatized system in $2 / 3 \mathrm{rd}$ of the districts of Afghanistan. The system is based on district-level Veterinary Field Units (VFUs) each staffed by a qualified veterinarian, supported by para-vets, who are

linked at the village level to farmers trained in vaccinating and other basic animal health skills. These farmers are called Basic Veterinary Workers (BVWs). Farmers pay for medications and for the services rendered. The vets are supported at gradually decreasing levels of funding over a period of about three years, after which no further support will be given. The system is implemented through NGOs and monitored by five National Veterinary Officers employed by the project. 
The VFU posts are staffed mainly by vets from the former government veterinary department who, in general, are accustomed to providing free service and receiving a government salary. Some are finding it difficult to accept the privatization strategy. Considerable attention is being given to this aspect and to the linkage between the vets. and their BVWs.

The rural rehabilitation activities of the Food and Agriculture Organization (FAO) illustrate the goal-driven flexibility and success of UN agencies in the face of unprecedented obstacles.

\section{FAO's Programme}

Firstly, from 1988 - 1993 the programme focused on emergency and rehabilitation assistance to encourage the return of refugees by restoring food production of (mainly) the staple crops through a package of inputs, namely;

- irrigation rehabilitation.

- improved seed and matching fertilizer through both supplying from outside Afghanistan and also through incountry production.

- horticulture planting material.

- protection of crops from migratory pests.

Secondly, a rehabilitation phase from 1993 - 1997 (while still continuing relief and emergency activities in some areas) is to reduce food losses in the livestock sector by provision of sustainable animal health services, to diversify and increase national food production capacity and, in 1995 - 1997 to initiate improvements in the management of the renewable natural resources of Afghanistan, agricultural diversification and secondary processing. 


\subsection{Irrigation Rehabilitation}

Photographs 1 and 2 demonstrate the effects of war-particularly the flight of rural communities - on irrigated agriculture; namely waterlogged, saline unproductive prime land, and damaged, dry irrigation canals.

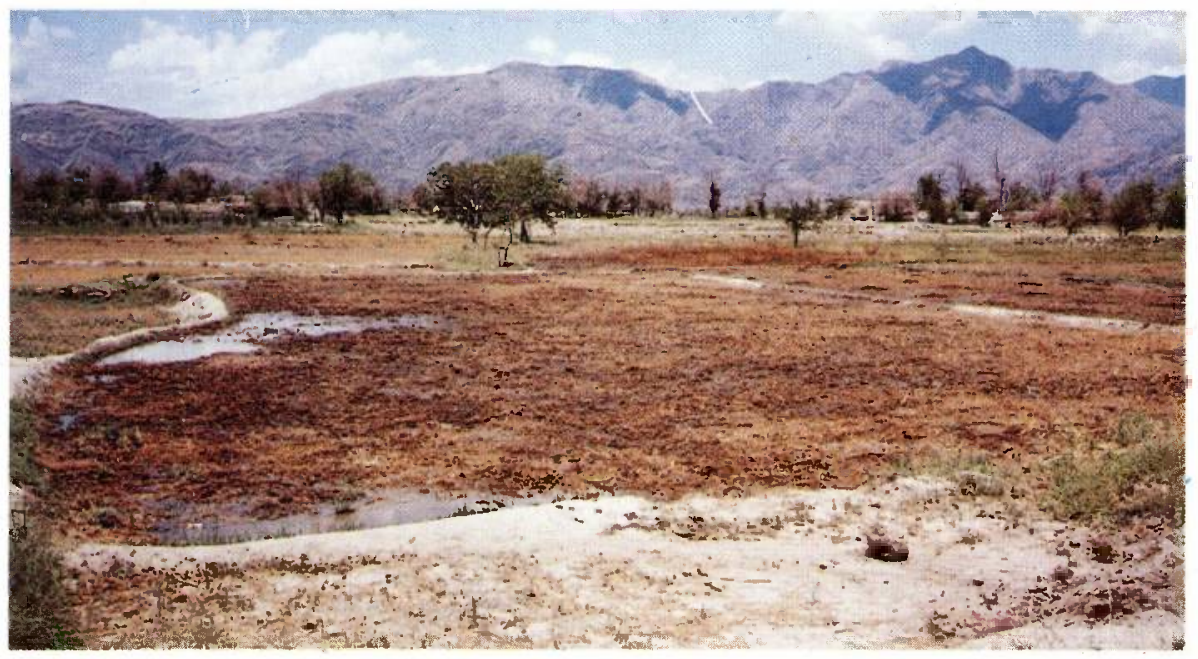

Photo 1

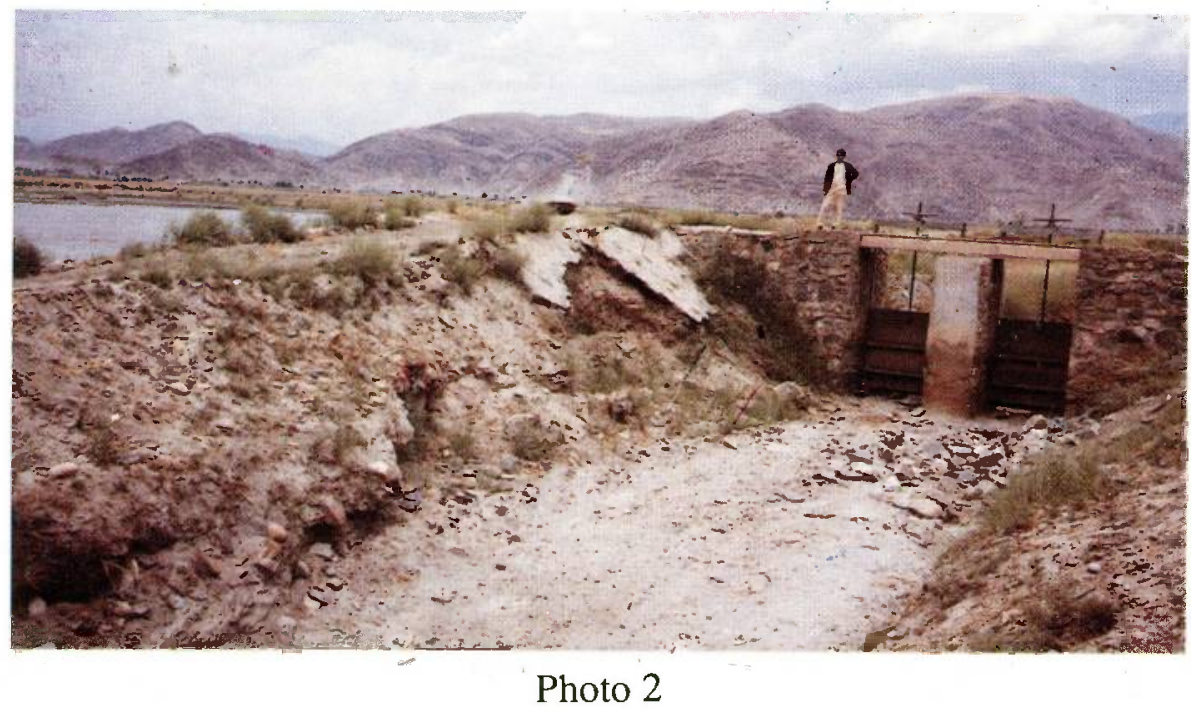


However, through community level decision-making in dialogue with FAO's Afghan irrigation engineers a plan is developed, community resources are mobilized (photo 3 ) and the canal is repaired (photo 4).

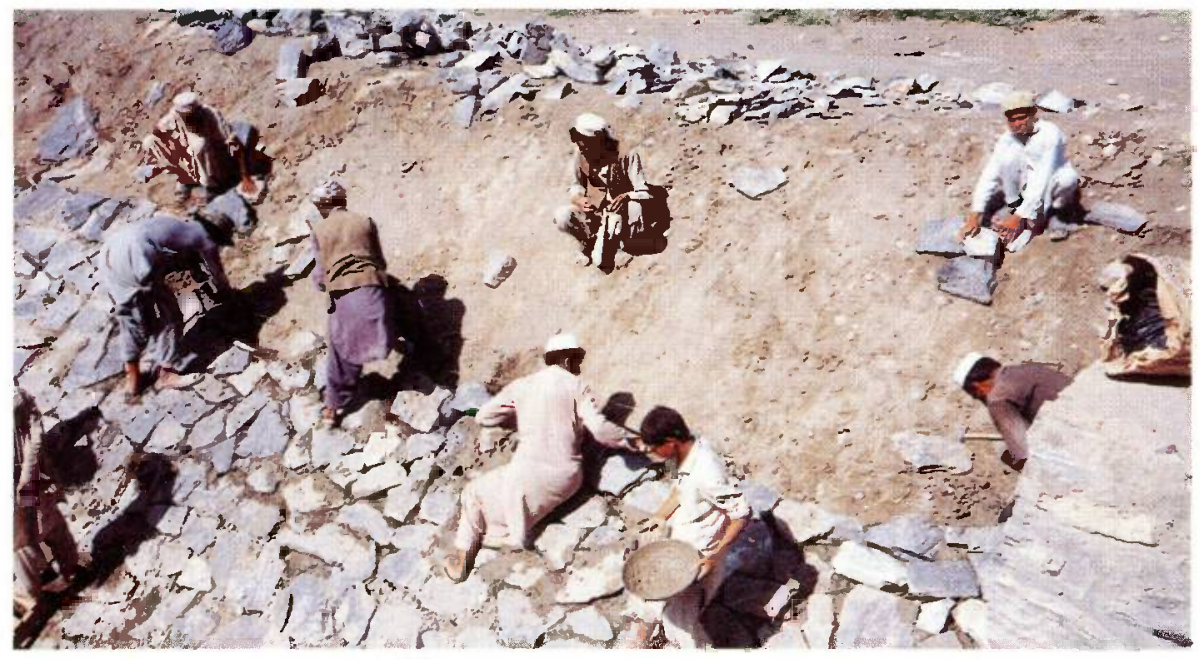

Photo 3

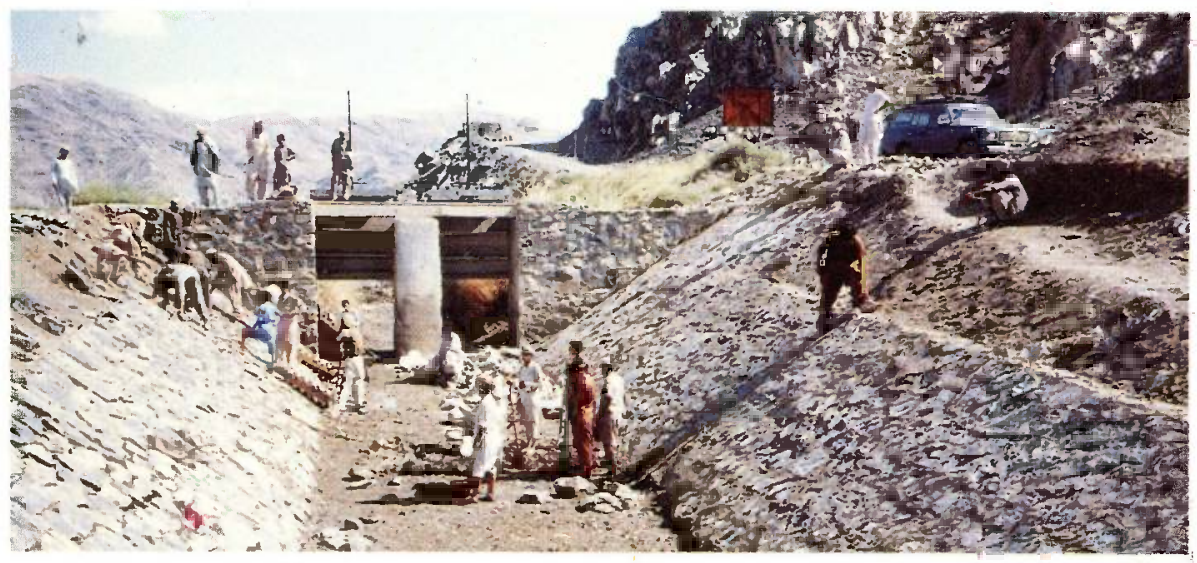

Photo 4 
In Paktia province, with funds from Japan and Germany provided through UNOCHA funding during 1992 - 94, canals totaling $144 \mathrm{~km}$ were repaired. Annually cropped areas increased from 472 ha to 12,245 ha. Similar results were achieved in Kunar province. This work, under limited funding, is continuing. The consequence of implementing this plan with village communities is a return to high levels of productivity; summer crops - maize (photo 5) and winter crops - wheat (photo 6).

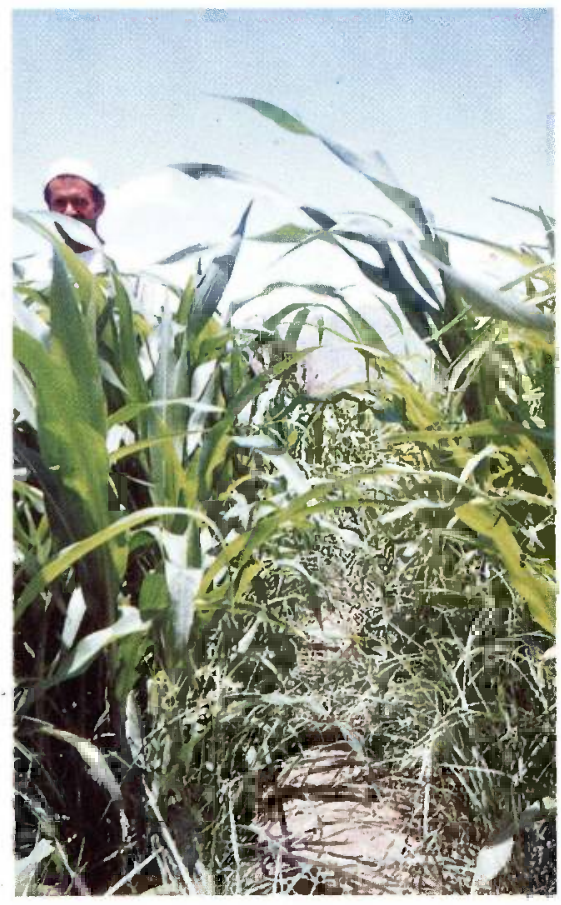

Photo 5

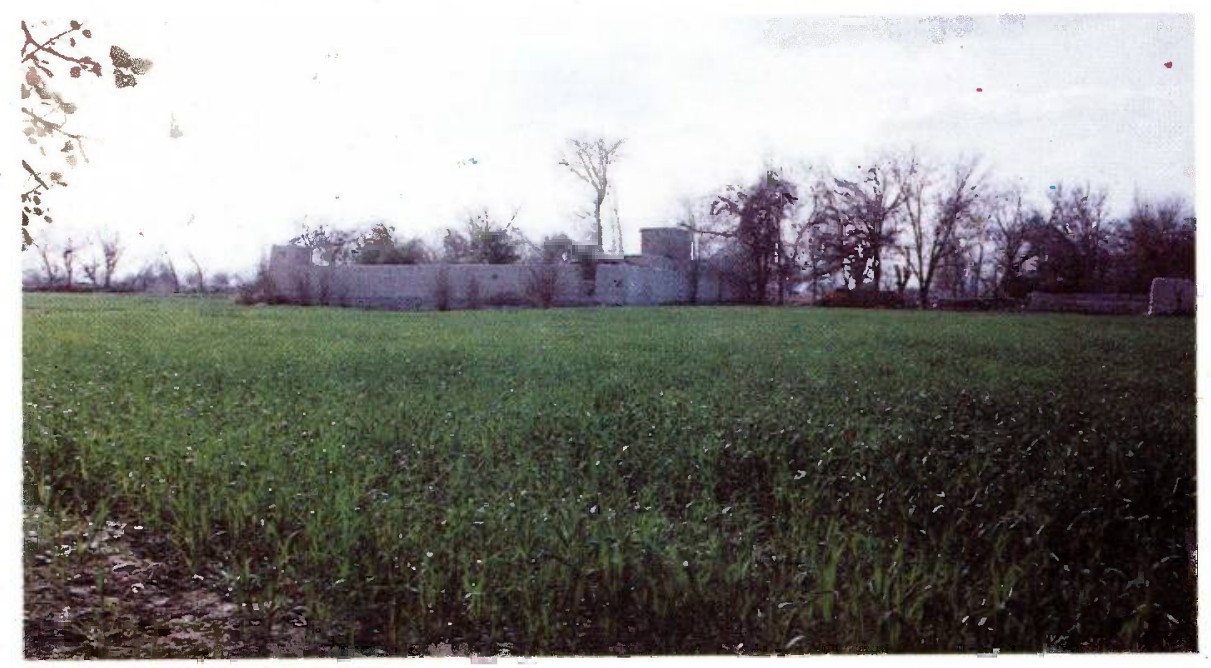

Photo 6 


\subsection{Seed supply and production with matching fertilizer}

\section{I) Winter crops}

With substantial assistance from the European Union, a programme of cross-border seed supply and in-country seed production with matching fertilizer was established in 1988, and is continuing.

The following figures $(2-8)$ show, in essence, the development through experience of an increased capacity, year by year, to deliver seeds and matching fertilizer, much of it in units of only 5 MT per village, to rural communities. Total deliveries of winter crop seeds from 1989 - 1995 was 24,500 MT.

The programme's success can be attributed to the following factors.

- The programme responded to expressed needs of rural com munities.

- $\quad$ Village communities decided on seed allocations to farmers and monitored production.

- A close implementing partnership with NGOs who were able

to deliver to otherwise inaccessible districts.

- Encouragement of the transfer of seed between farmers through traditional channels.

- $\quad$ Production of large quantities of seed in-country (centered in Mazar-I-Sharif and Herat) through the Improved Seed Enter prise.

- $\quad$ Protection of crops in the north from Locust and Sunnpest. 


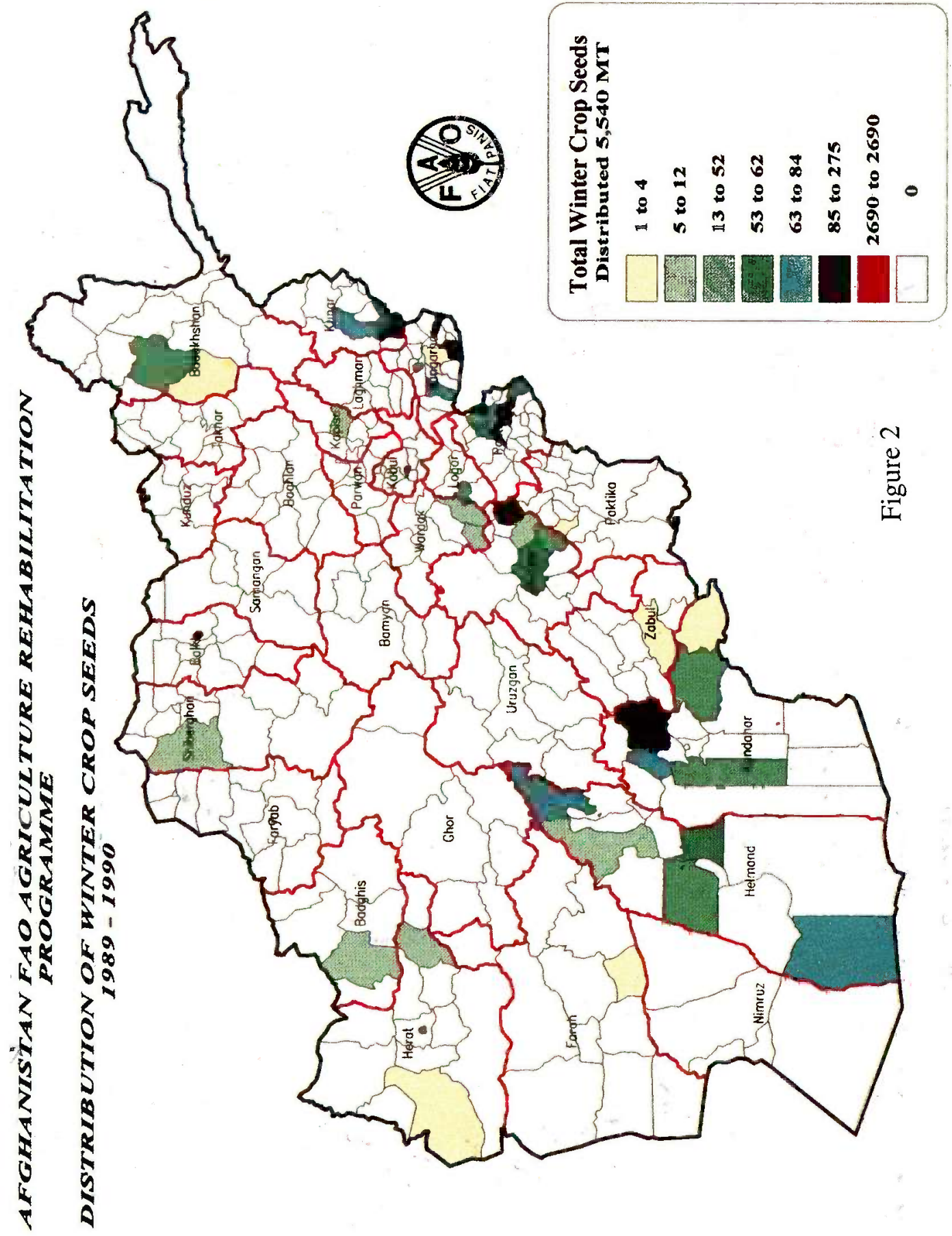




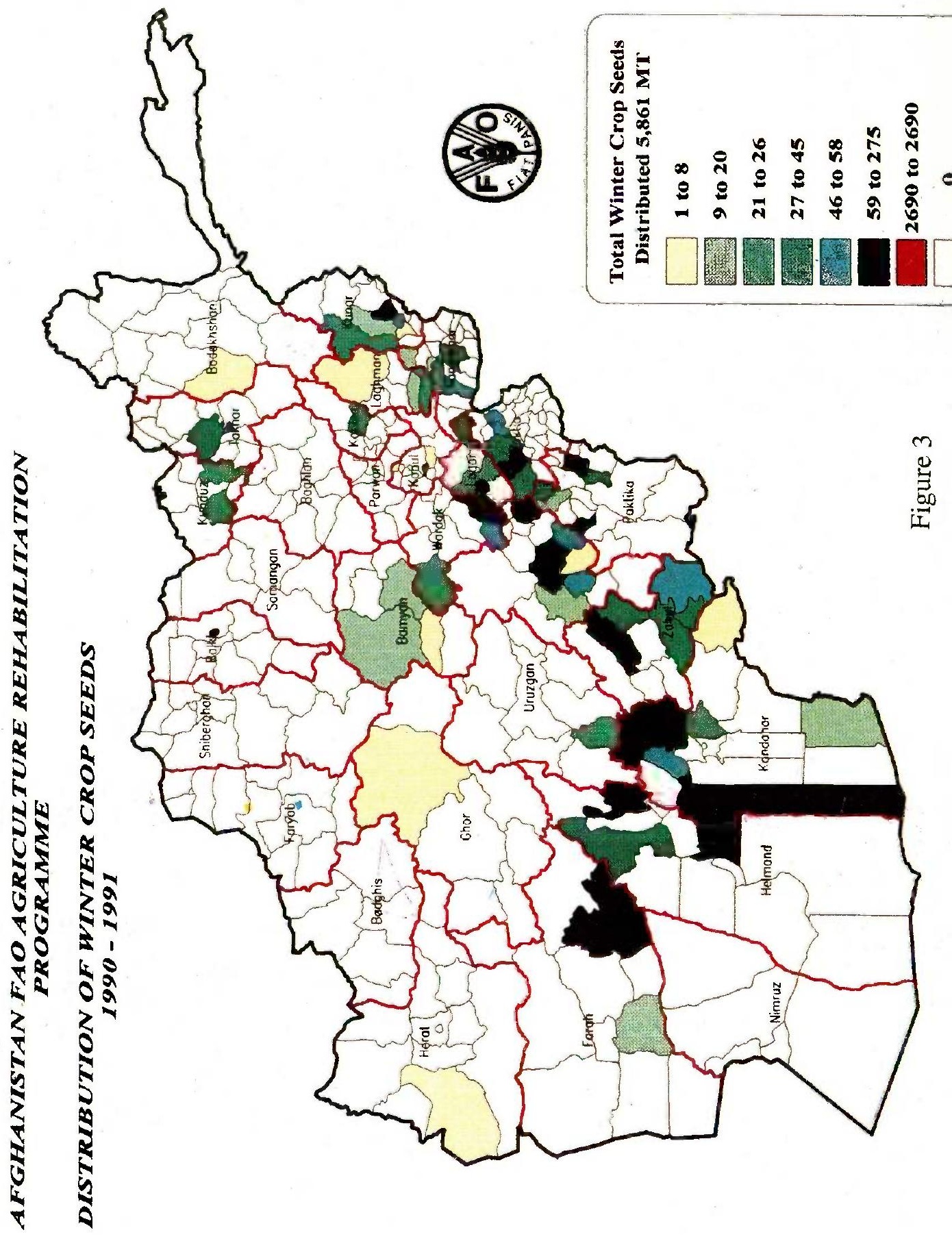




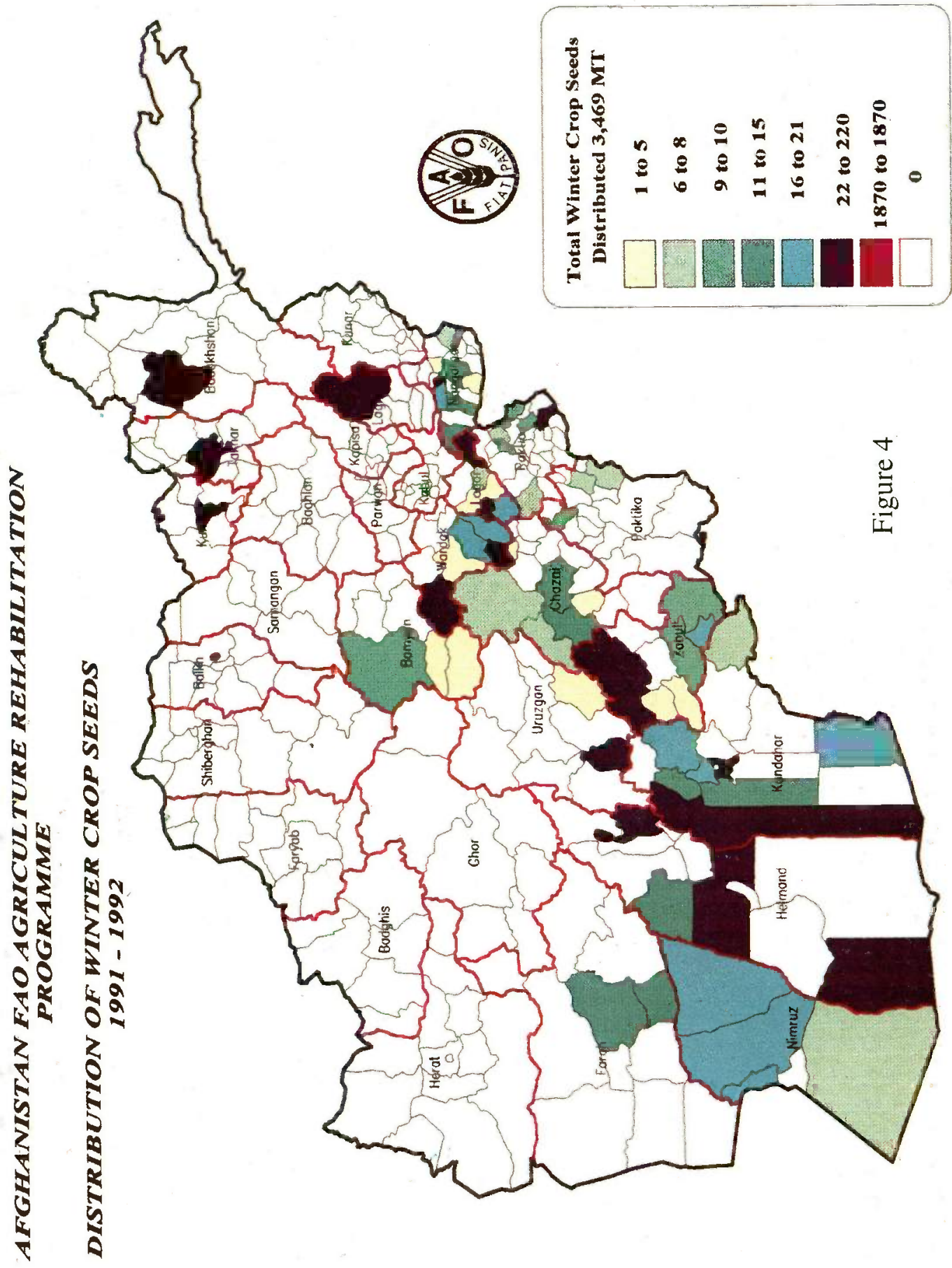




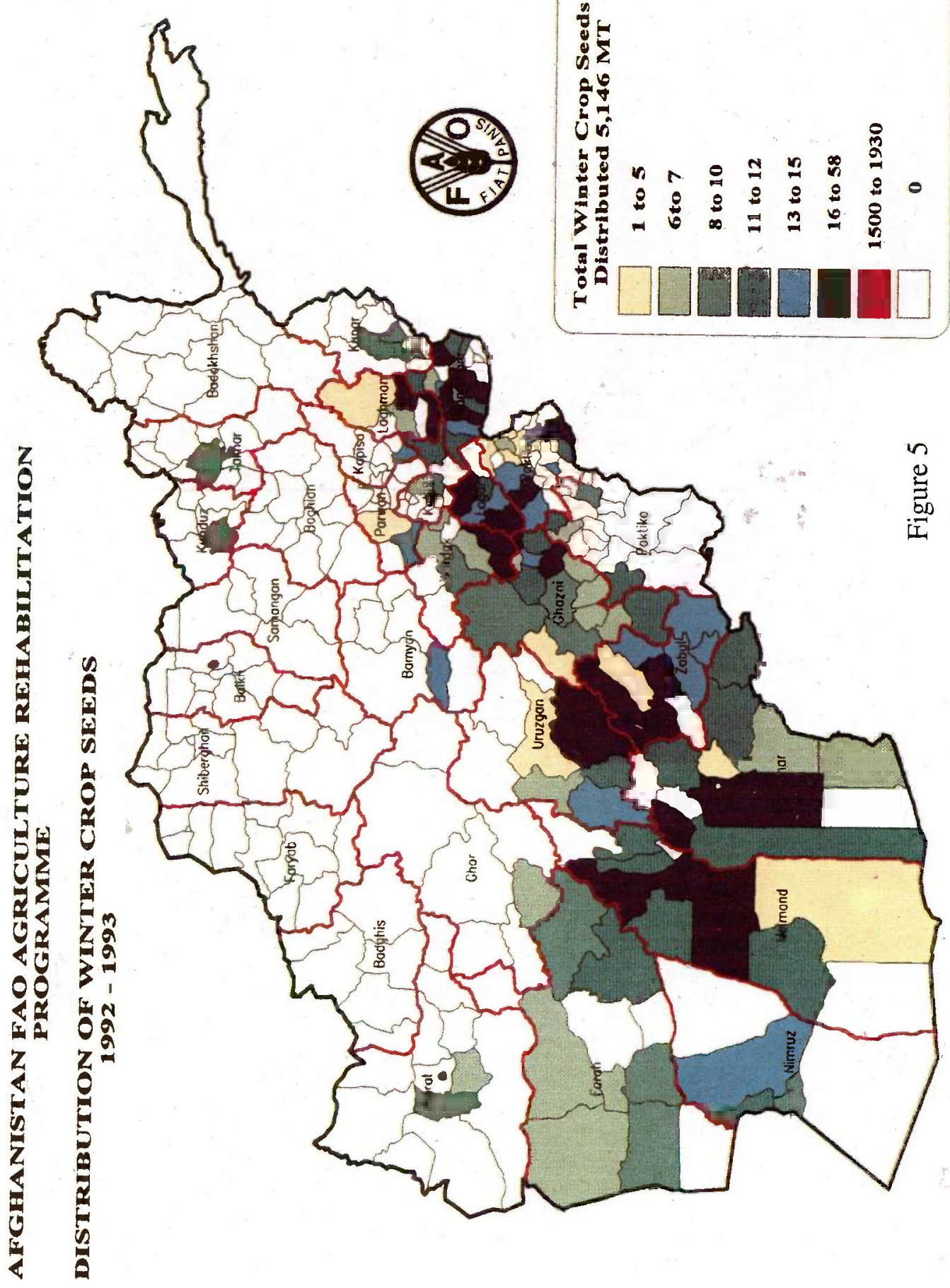




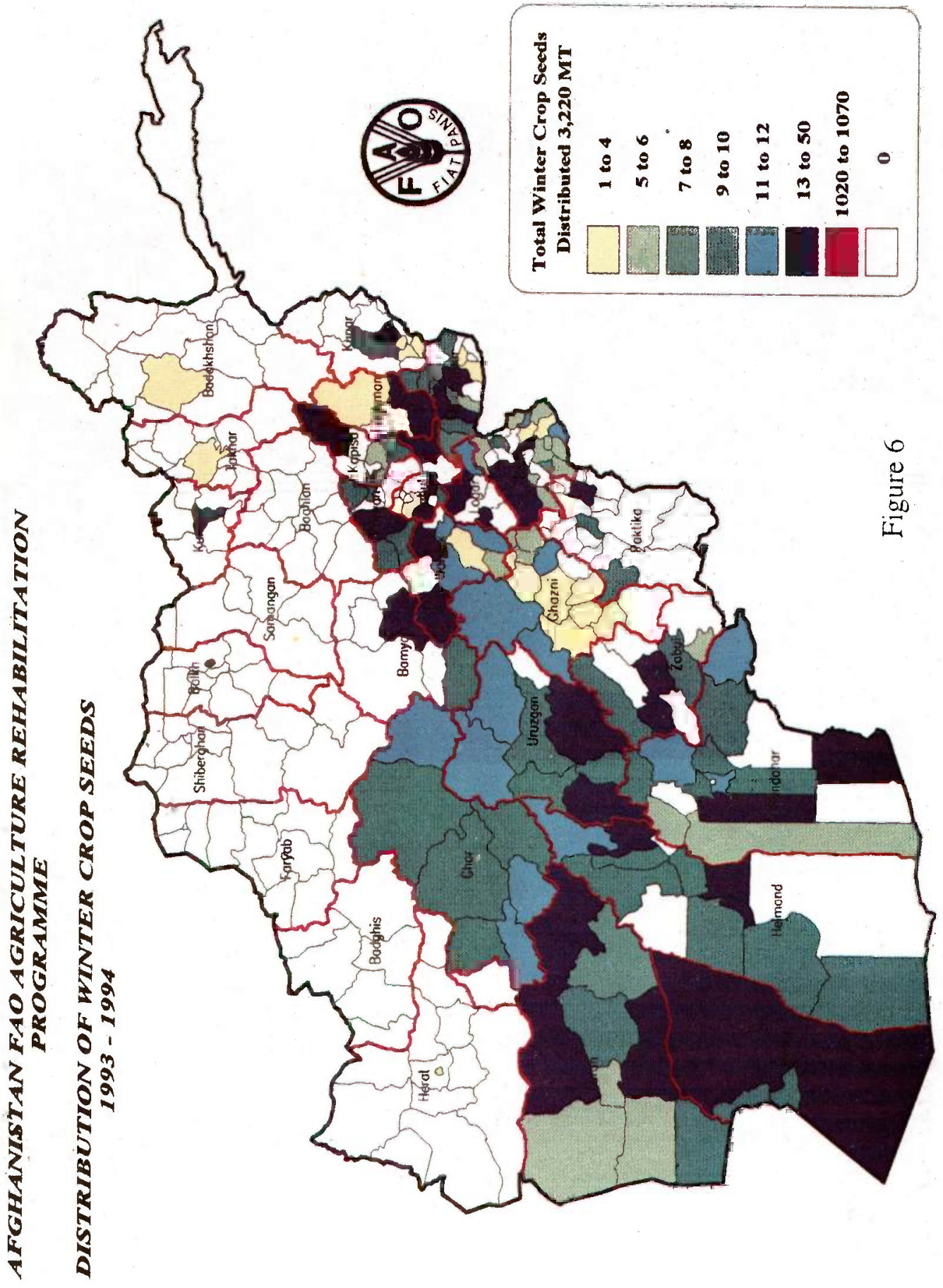




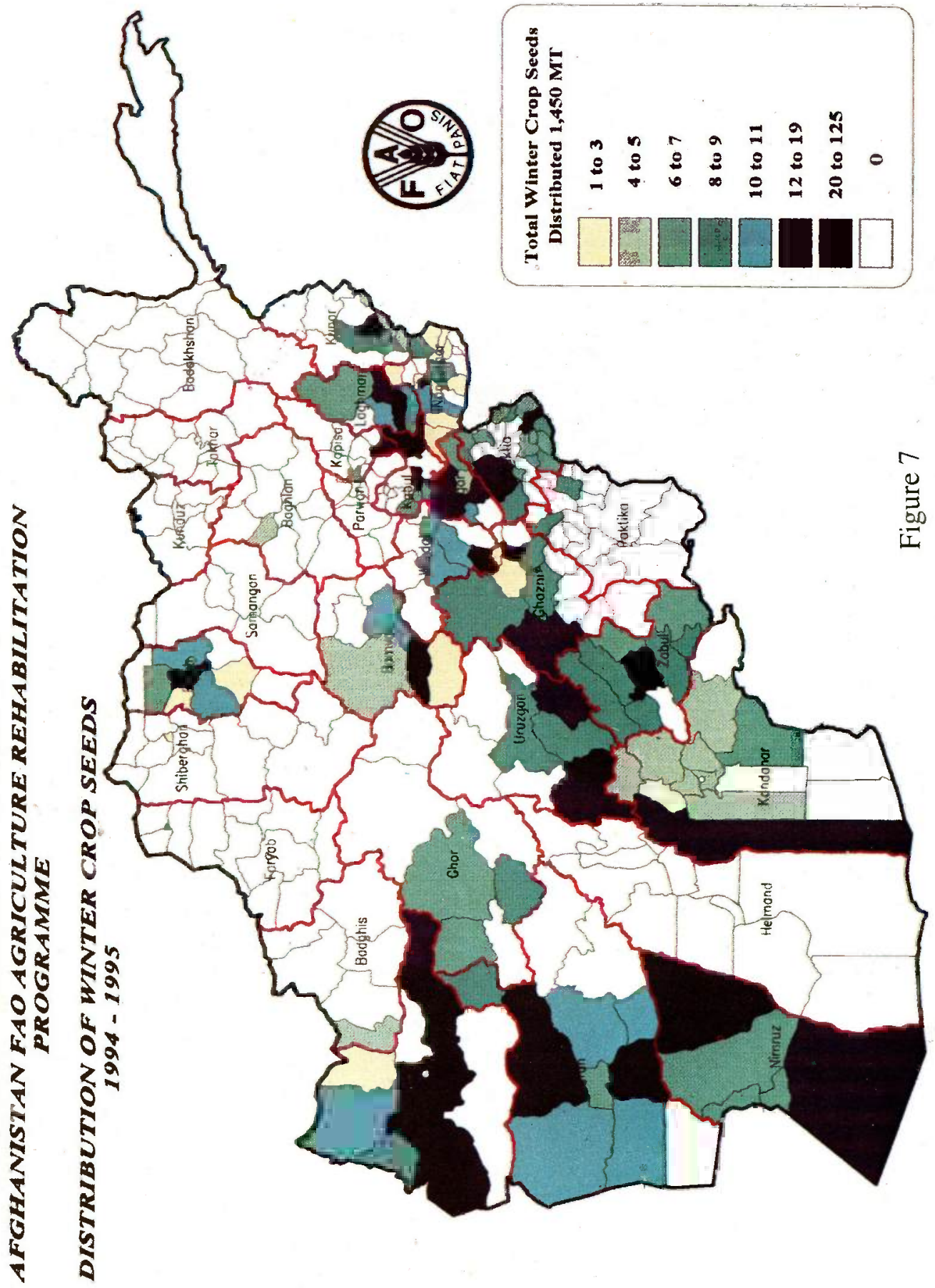




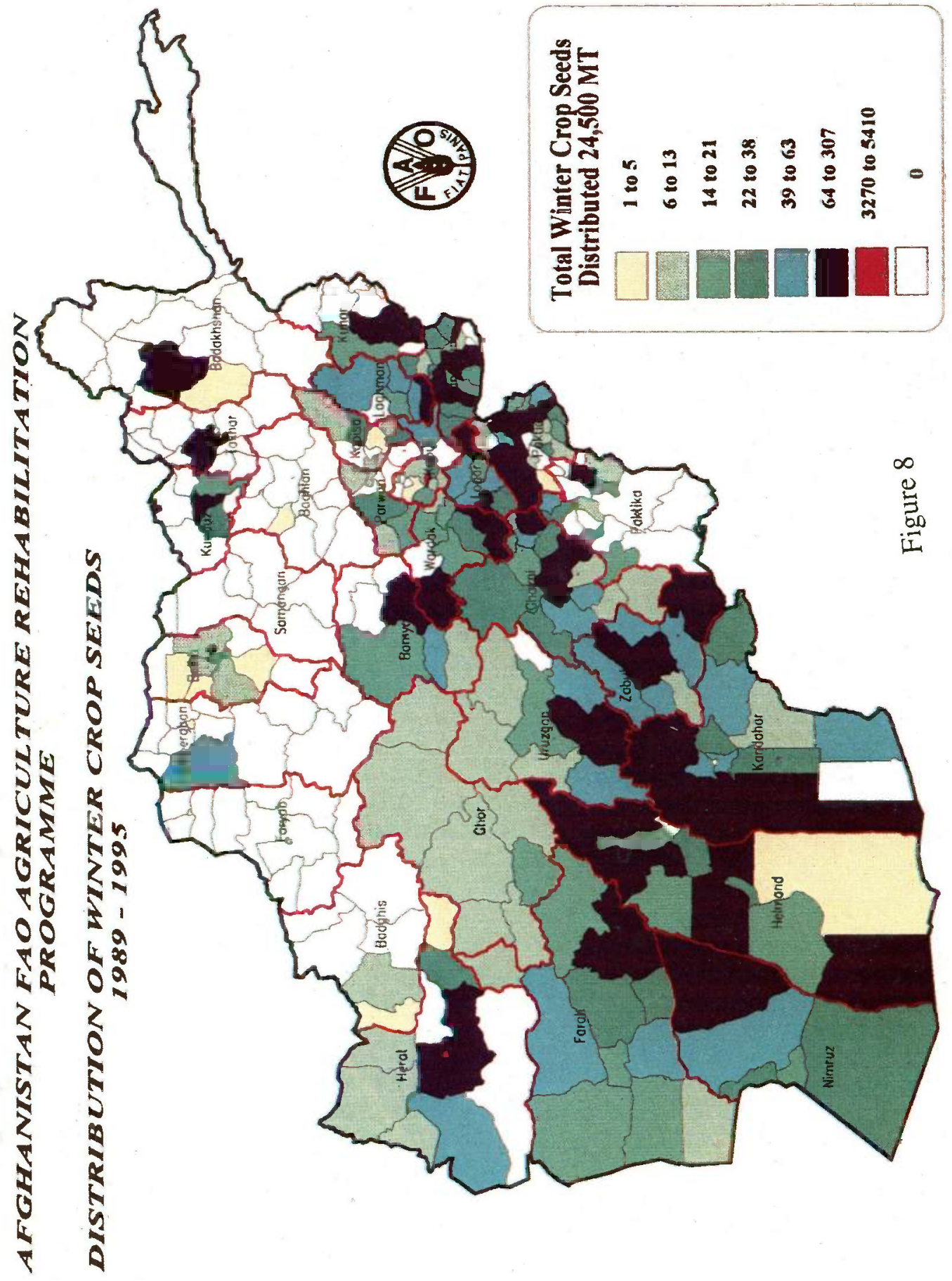




\section{II) Summer crops}

Summer crops (rice, maize, mung beans, sugarcane) and horticulture crops were distributed in the same way from 1990 1995: 4,300 MT of summer crop seed (figure 9).

\section{AFGHANISTAN FAO AGRICULTURE REHABILITATION \\ PROGRAMME}

\section{DISTRIBUTION OF SUMMER CROP SEEDS}

$1990-1995$

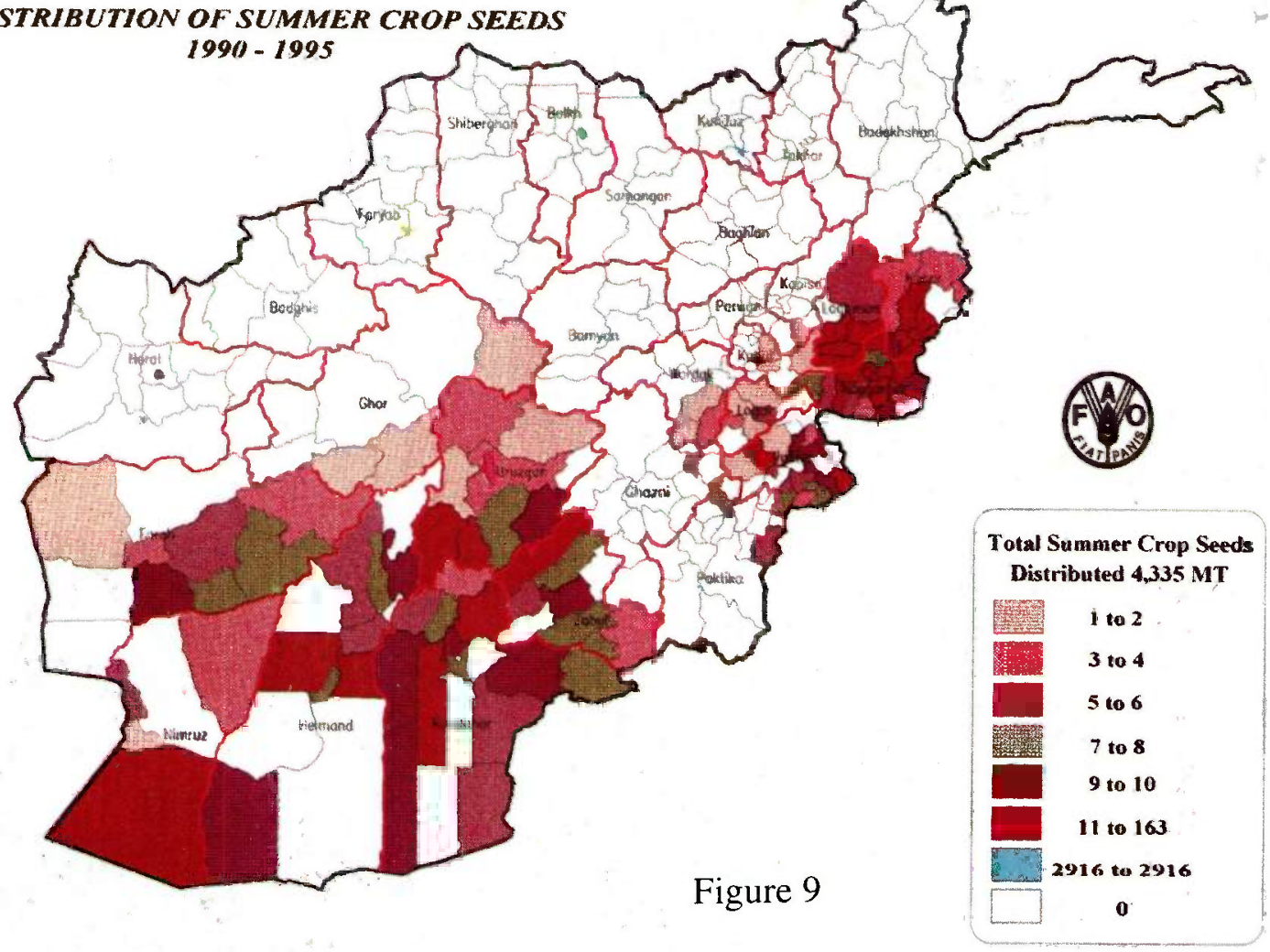

Under the umbrella crops programme funded by UNDP and with substantial support from the European Union and SIDA, FAO with its Implemting Partners, is now able to focus primarily on in-country seed production and the substantial strengthening of Afghanistan's capacity for variety testing based on the prior work of NGOs, particularly the Swedish Committee for Afghanistan. 


\section{III) Horticulture}

Since 1990 over $1,000,000$ horticultural saplings have been distributed as shown in figure 10.

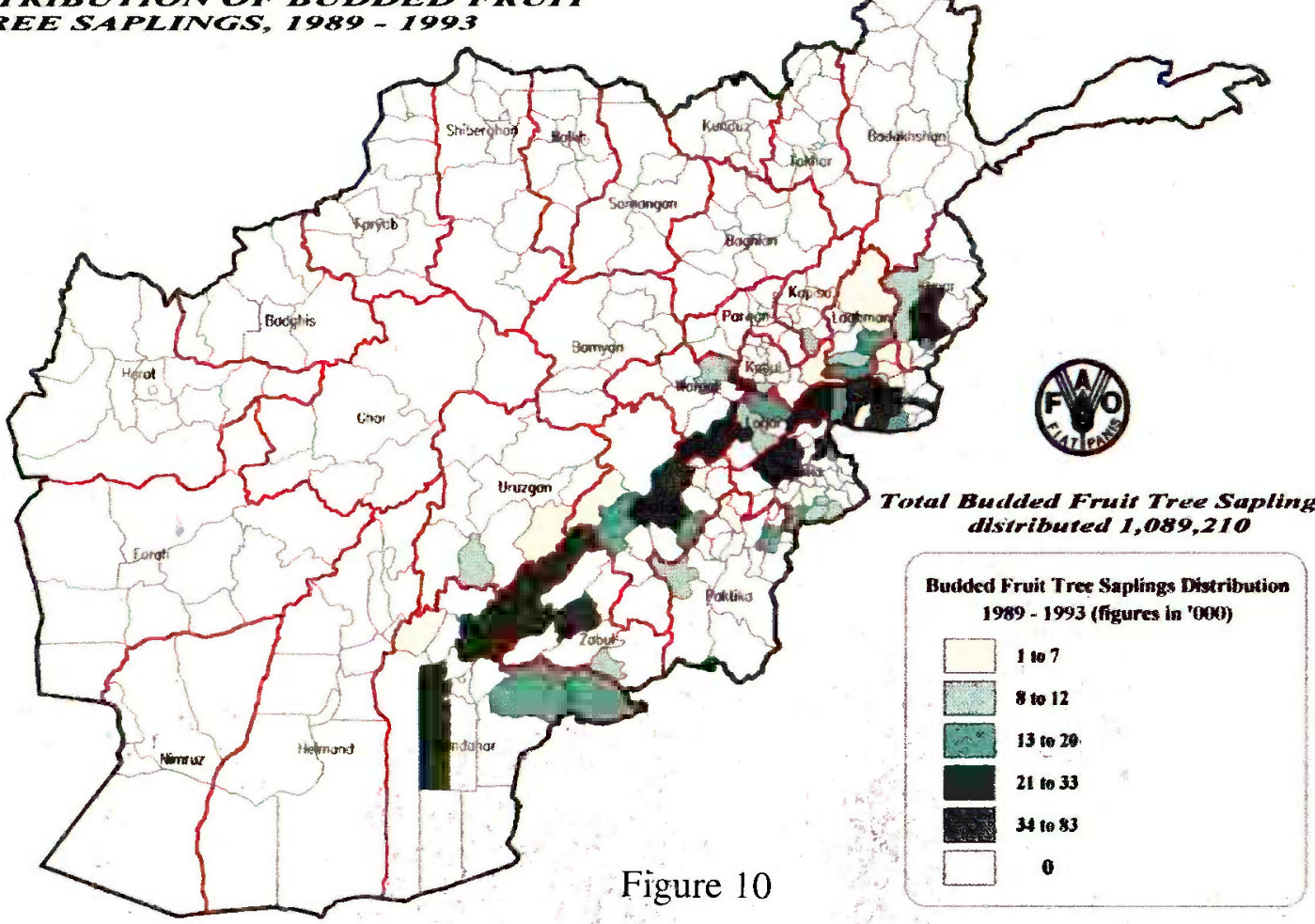


The horticulture sub-component carried out a thorough evaluation of the existing horticultural activities in mid - 1995 and a total of 69 fruit tree nurseries in the east and southern Afghanistan will continue to receive support in terms of inputs and technical management advice.

FAO's strategy will continue to encourage sustainability through private, small, decentralized nurseries. FAO staff will work directly with nursery managers and staff providing technical guidance and management advice. Plans are underway to establish a number of fruit tree nurseries in northern and western Afghanistan.

A scheme for the sound development of increased and improved vegetable production along with vegetable seed production in Afghanistan is being developed.

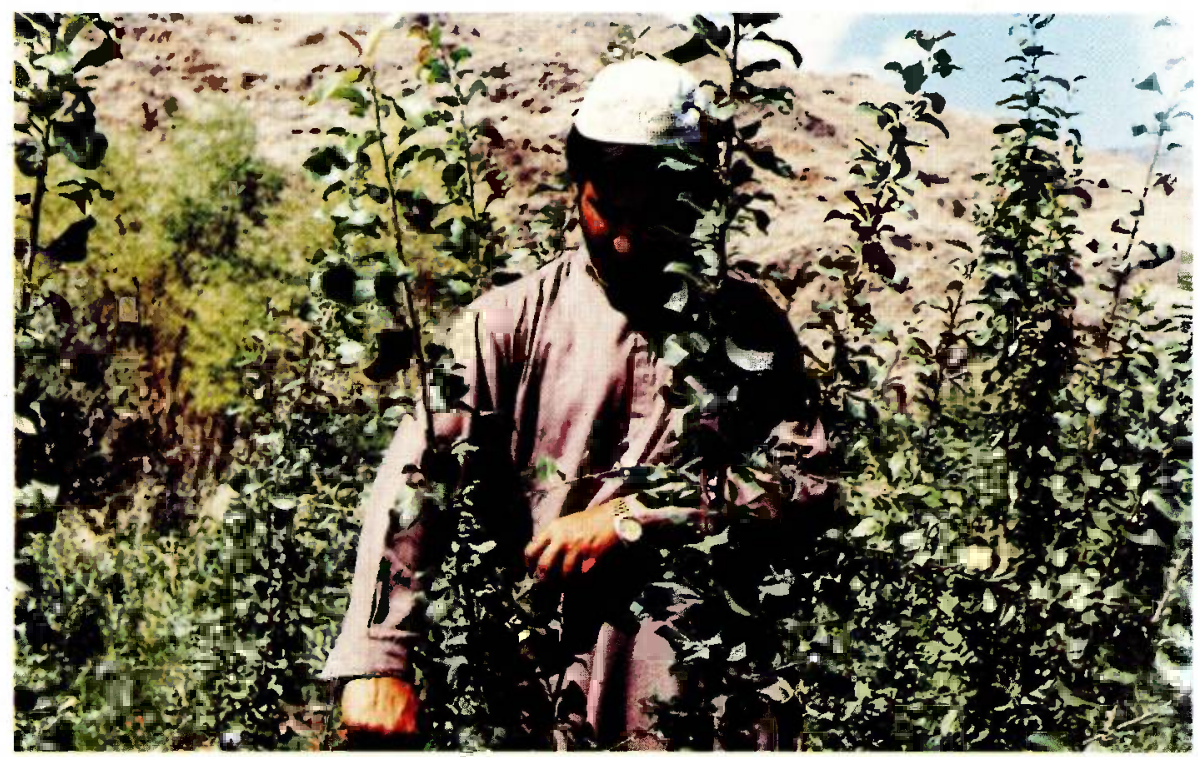

Photo 7 


\subsection{Livestock Health and Production}

\section{I) Health}

What is not generally well known is that, in addition to the contribution of livestock to subsistence needs, between $60-80 \%$ of household cash income also is derived from livestock. For two reasons, therefore, the control of livestock diseases is as important as crop production in restoring food supply to rural families. And the establishment of veterinary clinics has been as dramatic as the spread of improved seed; from 70 government clinics national wide before the war, to nearly 240 districts veterinary networks in 1995.

Figure 11 shows the distribution of Veterinary Field Units (VFUs) in 1995, which cover 2/3rd of the districts of Afghanistan.

DCATHON OF DISTRICT NETERINARY UNITS MAY 1995

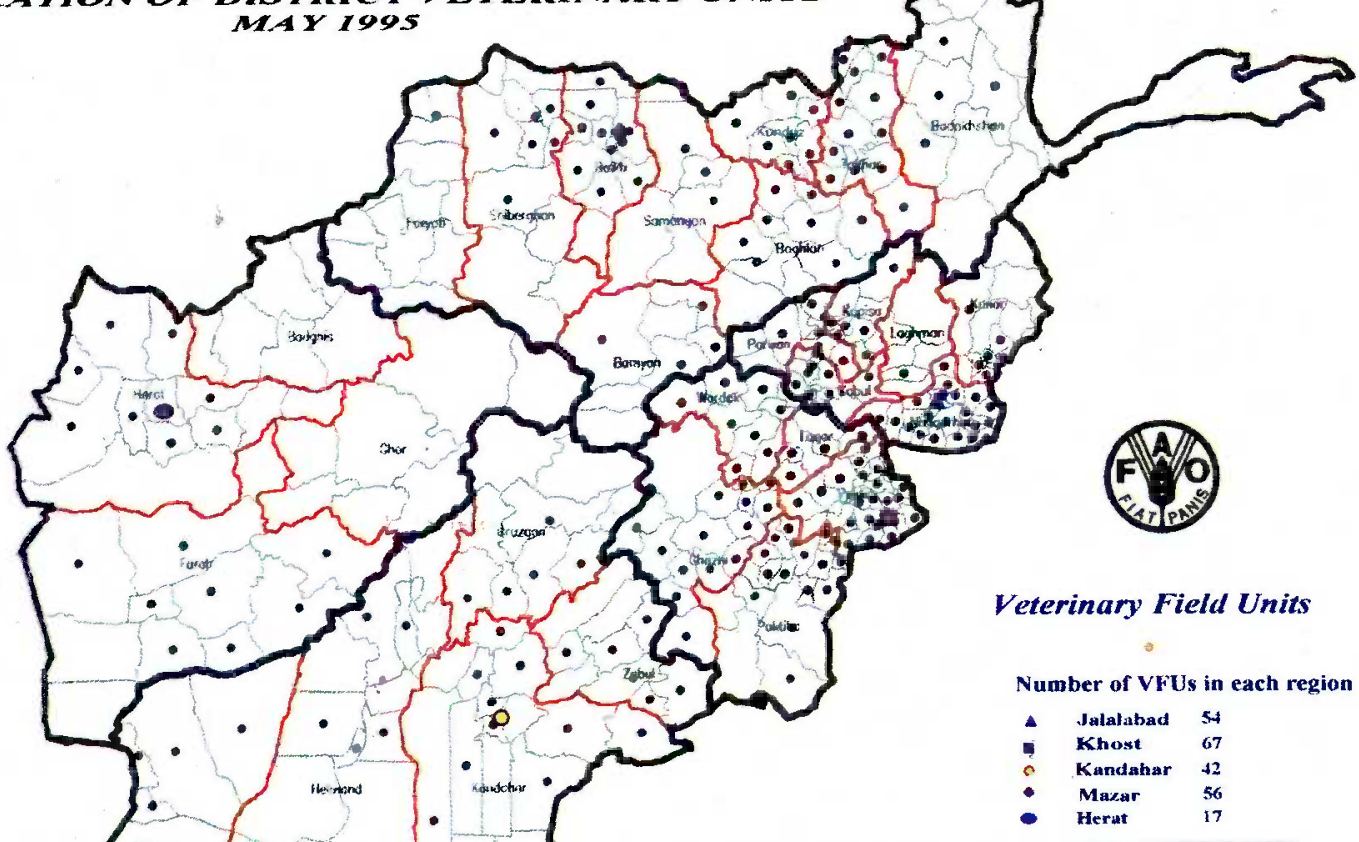

Figure 11

\begin{tabular}{|lr|}
\hline Total 236 F FUs \\
\hline
\end{tabular} 
They are established on the following principles:

A veterinarian (usually a graduate from Kabul University) supported by para-vets is established at district level. At the village level farmers called Basic Veterinary Workers (BVWs) chosen by the community are given training in vaccination and simple treatments. Livestock owners pay the full cost of medications and treatments to either the Vet. or the BVW.

Establishing the user-pays system is being strongly encouraged by steadily decreasing levels of project salary support to veterinarians and para-vets. BVWs receive no salary.

An example of the success to date of this programme is that, in the second half of 1994 12,000,000 vaccinations provided primarily by the European Union and treatments were administrated by vets and BVWs trained by FAO. An outbreak of rinderpest around Khost in mid-1995 was contained through a rapid response from FAO and the veterinarians in the area. 
Photographs $8 \& 9$ show veterinarians at work, both male and female.

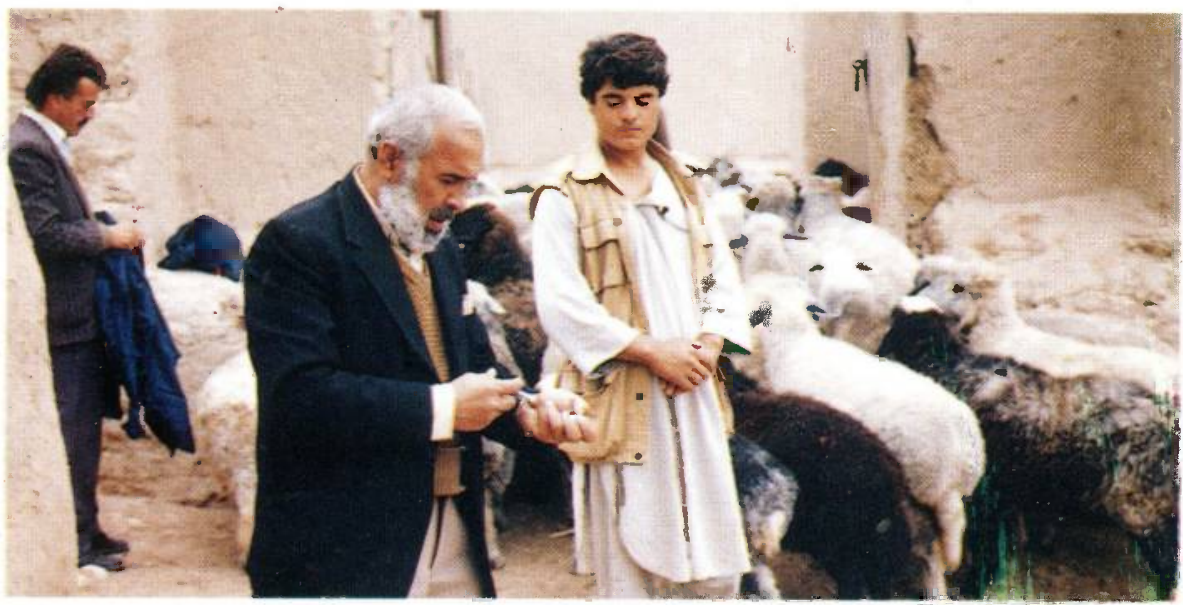

Photo 8

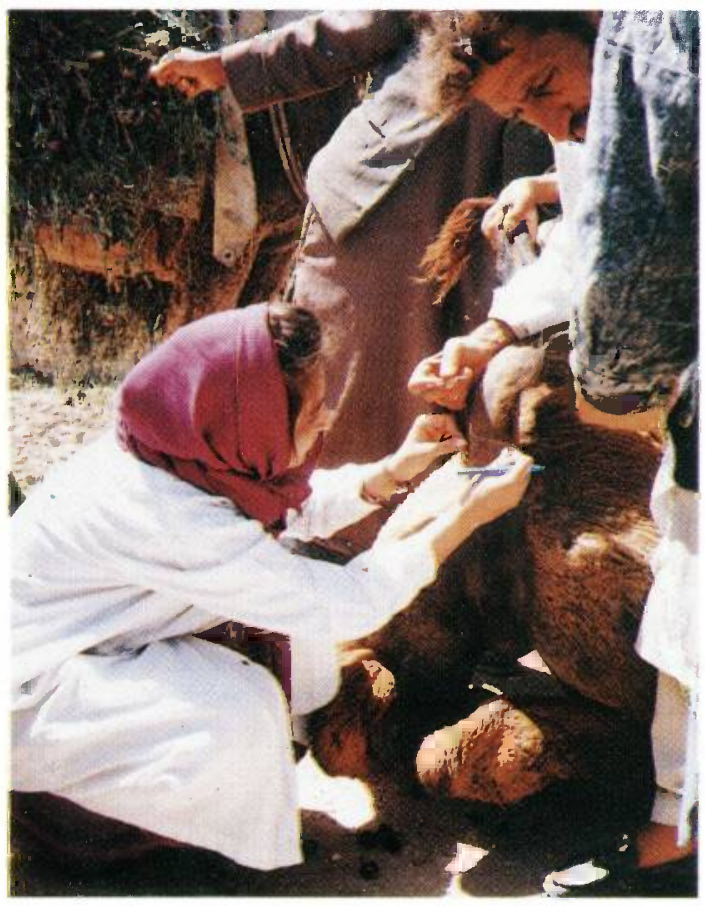

Photo 9 


\section{II) Poultry Production}

Poultry production and training centers are being established in two regions. These will be the mother farms which will meet the needs for fertile eggs for up to 200 poultry units at village level. The first mother farm has been established at Lashkar Gah in Helmand province. To date 60 men and 10 women, as managers of village units, have been trained. To be considered for training, farmers must firstly have paid $75 \%$ of the cost of their incubators: the first batch of 400 fertile eggs is provided by the programme.

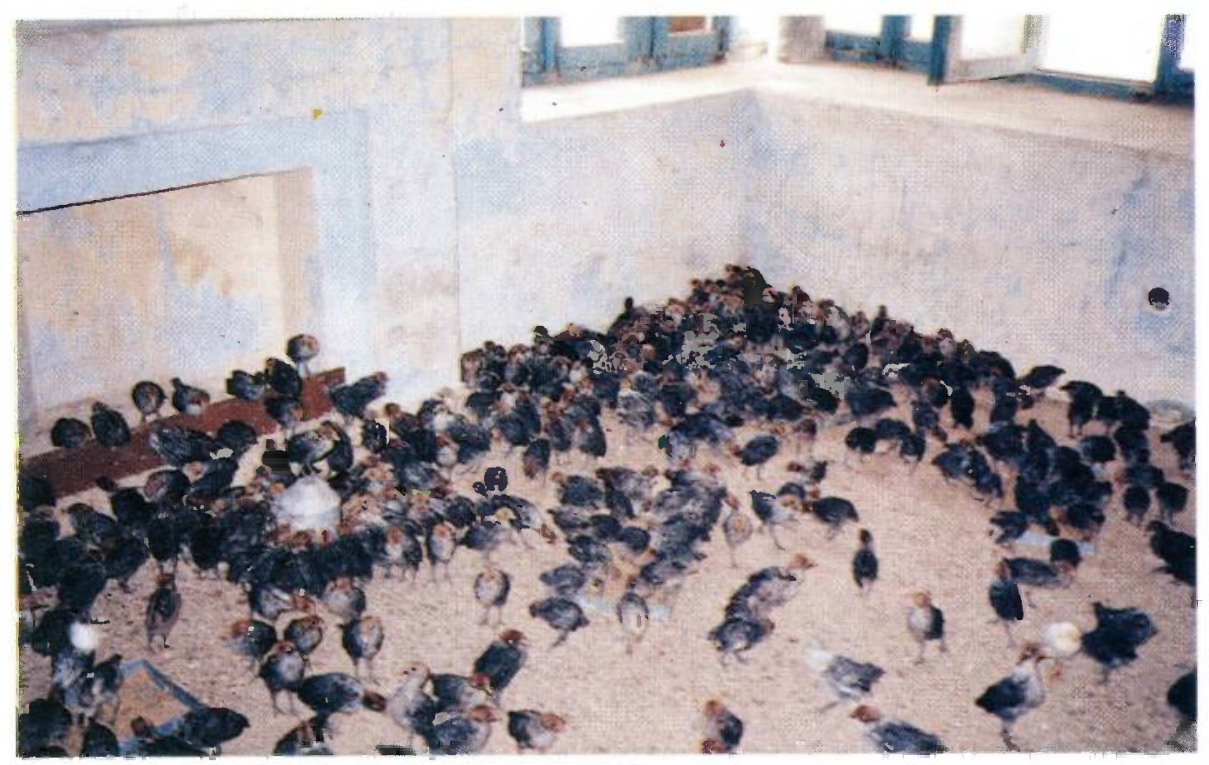

Photo 10 


\section{Promoting peace}

This programme is promoting peace in Afghanistan. For example, many Afghans have put down the gun and picked up the syringe as paravets or basic veterinary workers in the livestock programme. If the programme is curtailed this process will suffer.

More generally, when people are fed, employed and have at least some income then a few of the predisposing causes of conflict have been removed. Furthermore, as communities are re-established, people direct their energies to resuming control over their own affairs. 'Resuming control' means, at least in part, taking and implementing decisions which impact on the whole community, which strengthens cohesion. A cohesive community is able to resolve, internally, disputes between its members. A cohesive community is also able to select from its membership those who will represent them responsibly at higher levels of society. These factors contribute significantly to creating peace in Afghanistan.

\section{Immediate needs}

Our obligation, firstly, is to sustain our present activities and to expand to a nationwide programme. This is being carried out through our two main programmes funded by UNDP; AFG/93/ 004 Livestock and AFG/94/002 - Food/Crop Production. However, their resources are not adequate to cover the emergency rehabilitation requirements of Afghanistan agriculture and therefore, there is an urgent need for cost sharing assistance.

Secondly our task is to diversify the food base in order to increase food security, and to increase off-farm activities. This will add value to the basic agricultural products and so increase job opportunities and raise rural incomes, particularly for women. Sericulture, social forestry and poultry production would appear to be the highest priorities. 


\section{Cost - sharing priorities}

In view of the large national deficit in grain production, an increase in food production in food deficit areas is the main focus of the emergency component of FAO's agriculture programme, funded by UNDP. In order to achieve this, essential fertilizers will be provided alongside the distribution of improved seeds on a farmer-pays basis. Prevention and control of destructive migratory pests; particularly Moroccan locust and sunnpest in Northern Afghanistan, the traditional grain basket of the country, will also be vital. In 1995 the population of Moroccan locust was the largest for at least 20 years and could not be fully controlled. This means that large reserves of eggs will pose a potentially serious threat to the 1996 spring wheat crop. Therefore, additional land-based equipment to avoid areal spraying is needed to be prepared to attack the hopper bands.

Effective diagnosis and control of dangerous livestock diseases and provision of improved fodder, particularly in the winter period, will ensure increased livestock production. The establishment of village poultry production units will rapidly. increase protein availability at village level and will generate income for villagers to set up their own small hatchery businesses. These activities will in particular focus on the poorest districts of Badakhshan province and the Kabul area. Sericulture production is aimed at increasing the income of rural women.

Returning refugees will be assisted with emergency repairs of the irrigation and flood protection structures in the most flood prone areas. Lack of maintenance and damage due to the war have led to the collapse of many irrigation systems, including the silting of canals. Projects included in this appeal will ensure emergency rehabilitation of traditional irrigation systems in areas to which refugees are waiting to return, keeping in mind the long-term needs for complete rehabilitation of the systems.

One-line summaries of these priorities are included in this brochure. 


\section{Conclusion}

The fourth national Agricultural Survey of Afghanistan carried out in 1993 by the Swedish Committee for Afghanistan (SCA) reported (amongst others) the following results:

- Of the 6,258 farmers interviewed nationally, 2,978 (48\%) reported that they have planted improved seed during the last four years. Farmers from the South East and South West zones, particularly Paktika, Kandahar and Paktia, reported the highest use of improved seed (in last four years) with $100 \%, 92 \%, 88 \%$ of farmers respectively. Most of the farmers $(61 \%)$ received their improved wheat seeds from NGOs, compared to $32 \%$ from the market and $7 \%$ from other sources.

- In the section on problems identified by farmers, answers were stratified and prioritized into 20 categories.

The effects of war was ranked as the least important of their problems.

The significant conclusion to be drawn from these finding is that, in general at the community level in rural areas, the country is at peace and people are rebuilding their lives. Through a participatory, people-centred approach, we should increase our support to them in their pursuit of that goal. 


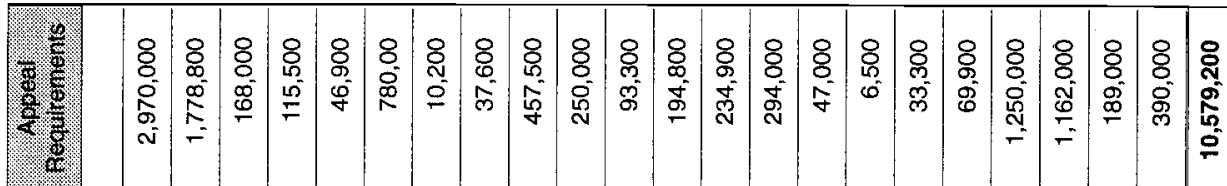

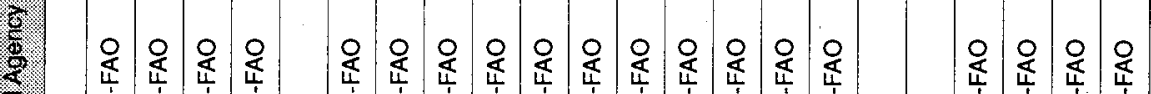

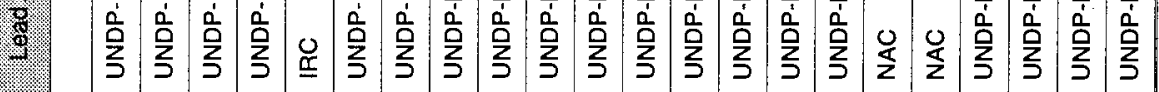

$\frac{2}{8}$

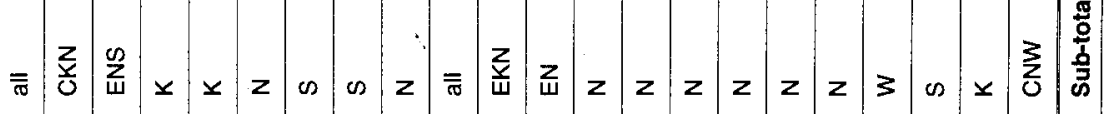

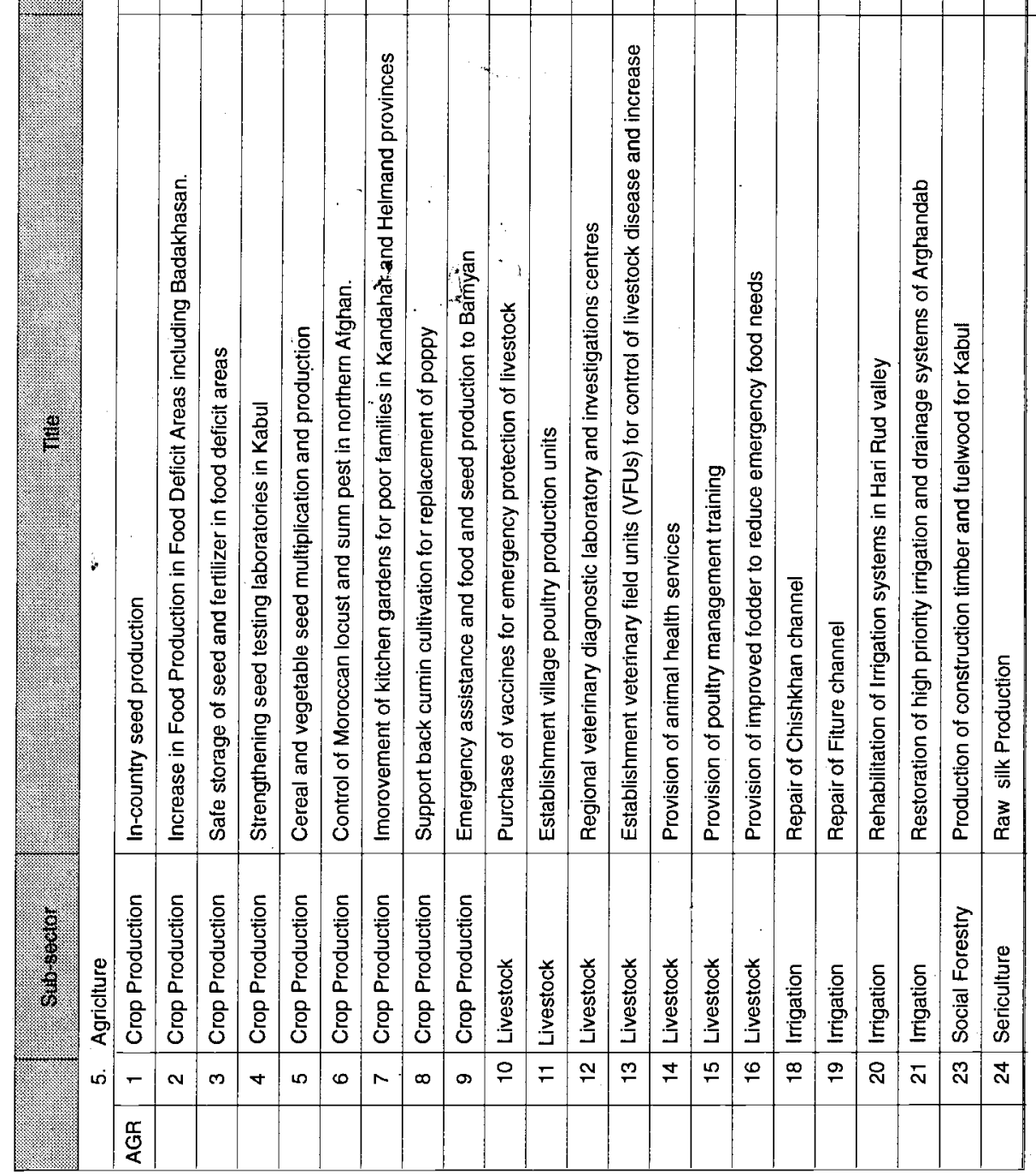



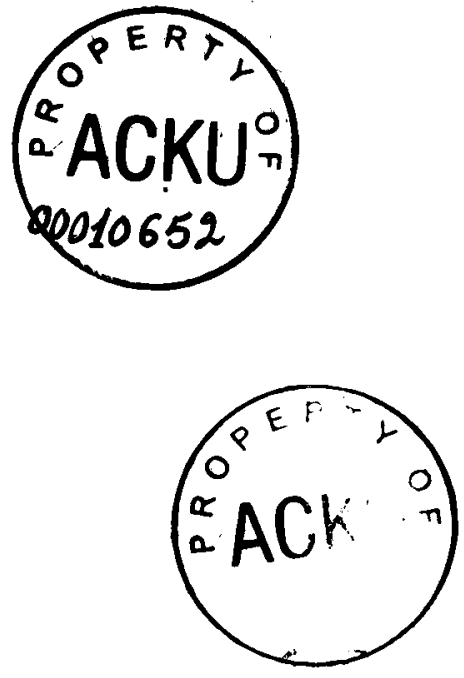

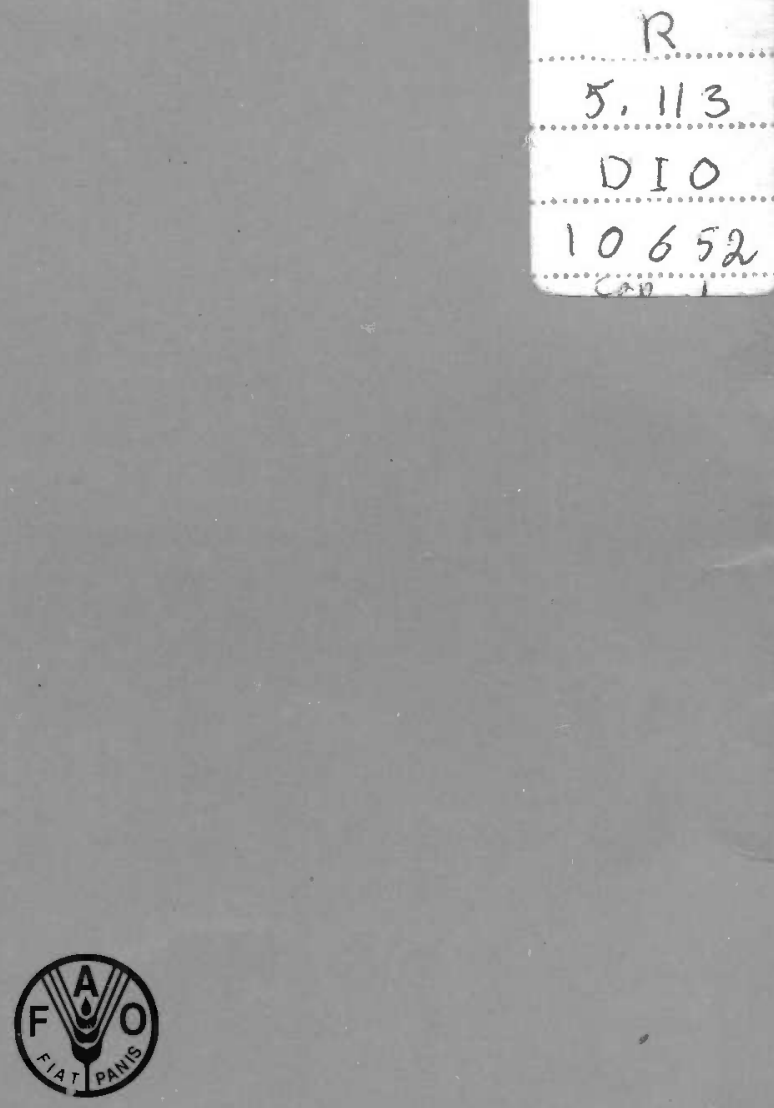

Food and Agriculture Organization of the United Nations

Produced by the

Office of FAO Afghanistan

Temporarily located in Islamabad

UN Boulevard, Diplomatic Enclave-1, Islamabad

Telephone: $221264,822072-822079$

Facsimile: $92-51-824371$

Telex: 5548 FAOIB PK 